\title{
PREGNANCY ASSOCIATED BREAST CANCER
}

\author{
IVA ANDRAŠEK ${ }^{1}$, ILIJA ALVIR ${ }^{2}$ and LIDIJA BEKETIĆ-OREŠKOVIĆ ${ }^{1,3}$ \\ ${ }^{1}$ Division of Radiotherapy and Internal Medicine Oncology, University Hospital for Tumors, \\ Sestre milosrdnice University Hospital Center, Zagreb, Croatia; \\ ${ }^{2}$ Deptartment of Gynecologic Oncology Surgery, University Hospital for Tumors, \\ Sestre milosrdnice University Hospital Center, Zagreb, Croatia; \\ ${ }^{3}$ Department of Clinical Oncology, School of Medicine, University of Zagreb, Zagreb, Croatia
}

\begin{abstract}
Summary
Pregnancy-associated breast cancer is a difficult psychosocial and health problem for the patient, demanding an individual multidisciplinary treatment approach. Due to the need for aggressive oncological treatment with minimal adverse effects on the growing fetus, numerous studies are carried out to find an optimal protocol, concerning the interest of both the mother and the child. Due to the physiological changes in the breasts in pregnancy, the diagnosis of breast cancer can be delayed and therefore patients have often higher clinical stage of the disease at initial presentation comparing to non-pregnant patients. Pregnancy termination due to breast cancer diagnosis had no effect on the prognosis of the patient, and longterm studies did not find a higher incidence of malignant disease in children who were exposed to chemotherapy in utero compared to the general population. Although prognosis data of those patients is controversial, recent studies have not found a worse outcome compared to breast cancer unrelated to pregnancy.
\end{abstract}

KEY WORDS: pregnancy, breast cancer, therapy, prognosis

\section{Sažetak}

\section{KARCINOM DOJKE U TRUDNOĆI}

Karcinom dojke povezan s trudnoćom teški je psihosocijalni i zdravstveni problem za pacijenticu i zahtjeva individualni multidisciplinarni pristup liječenju. Zbog potrebe za agresivnim onkološkim liječenjem, uz minimalne štetne utjecaje na rastući fetus, provode se brojne studije, čiji je zadatak pronaći optimalan protokol, vodeći se interesom i majke i djeteta. Zbog fizioloških promjena dojke tijekom trudnoće, može doći do kašnjenja u postavljanju dijagnoze karcinoma dojke i samim time višeg stadija bolesti pri inicijalnoj prezentaciji. Prekid trudnoće zbog dijagnoze karcinoma dojke nije mijenjao prognozu bolesti, a dugogodišnje studije nisu pokazale višu učestalost zloćudnih bolesti u djece intrauterino izložene kemoterapiji, u odnosu na opću populaciju. Iako su podaci o prognozi tih bolesnica kontroverzni, ipak većina novih studija nije ustanovila lošiji ishod u odnosu na bolesnice s karcinomom dojke nepovezanim sa trudnoćom.

KLJUČNE RIJEČI: trudnoća, karcinom dojke, terapija, prognoza

\section{INTRODUCTION}

Pregnancy-associated breast cancer (PABC) is defined as breast cancer diagnosed during pregnancy or in the first postpartum year.
PABC is a major health problem for both the patient and the multidisciplinary team. Although the oncologic care is based on that of the nonpregnant breast cancer patient, there are many challenges regarding the oncological and obstetri- 
cal aspects of care that need to be considered to deliver the best treatment plan for both the mother and the child.

\section{Epidemiology}

Breast cancer is one of the most common cancers diagnosed in pregnancy with the frequency approaching one in 3000 pregnancies (1). In women under the age of 30, up to 20 percent of breast cancers are pregnancy-associated, but only 5 percent of breast cancers diagnosed in women younger than 50 are pregnancy related (2). Given that more women are delaying childbirth into their thirties and forties, the incidence of pregnancyrelated breast cancer is expected to rise.

There is evidence suggesting a transient increase in breast cancer during the first 3-4 years following pregnancy. A Norwegian population based study showed a short-term increase in breast cancer after full-term pregnancy, with a peak 3-4 years after the delivery (3).

Carriers of the BRCA1 and BRCA2 mutations have an increased risk of developing breast cancer in pregnancy, in fact, they are significantly more likely to develop breast cancer by the age of 40 than nulliparous carriers, with each pregnancy increasing the risk (4).

\section{Diagnosis}

Breast cancer in pregnant patients is usually presented as a palpable mass (5). Most patients present with a painless palpable mass or breast skin thickening during breast feeding (6). Considering that, the first obstetrical exam during pregnancy should include a thorough breast exam with encouragement of self-examinations throughout the entire pregnancy and after delivery. Pregnancy-induced breast changes, such as enlargement, are thought to be some of the reasons of the delay of the diagnosis, and perhaps a poorer outcome. In pregnancy, ultrasonography is a more suitable diagnostic procedure than mammography and can help distinguish cystic and solid breast masses. If a biopsy is indicated by ultrasonography, further mammography must be performed to identify the range of lesions, including microcalcifications. Mammograms can be performed with the use of proper abdominal shielding. Reported sensitivity of mammography ranges from $63-78 \%$, owing to increased water content in the pregnant breast and loss of contrasting fat (7). The finding of a breast mass usually necessitates a biopsy or fine needle aspiration. It is necessary to inform the pathologist of the patient pregnancy because pregnant breast tissue is rapidly dividing and can be confused with rapidly dividing cancer cells.

Most studies have found that there are no major differences in the histology of breast cancer of pregnant and non-pregnant women (8). In 2012, Azim et al. published a case control study which included 65 patients diagnosed with breast cancer during pregnancy. They did not observe any significant histological differences between pregnant and non-pregnant patients (9).

\section{Treatment options}

Current National Comprehensive Cancer Network guidelines recommend pregnancy termination upon diagnosis of breast cancer in the first trimester of pregnancy. If the decision is continuation of pregnancy, the surgical procedure mastectomy with axillary dissection is the primary recommendation during the first trimester (10).

Depending on the pathohistological results, adjuvant chemotherapy should be administered after the end of the first trimester. Most regimens use combinations of doxorubicin, cyclophosphamide and fluorouracil. The use of weekly paclitaxel is considered acceptable if indicated by disease status. Selection of both local and systemic therapies are similar to those in non-pregnancy related breast cancer, however the timing differs. Adjuvant radiation therapy as well as hormone therapy should be reserved for the postpartum period, and chemotherapy should not be administered before the second trimester. The use of blue dye is contraindicated during surgical approaches in pregnancy, radiolabeled sulfur colloid appears to be safer for sentinel node biopsy (10).

If breast cancer is diagnosed during the second trimester or beginning of the third trimester, and the patient is a candidate, neoadjuvant chemotherapeutic approach to treatment is also an option, followed by surgery and postpartum radiation and endocrine therapy, depending on the indication (10).

Mastectomy or breast-conserving surgery with axillary staging is the recommended option for tumors diagnosed in the late third trimester, 
with adjuvant chemotherapy, postpartum radiation and endocrine therapy, depending on the pathohistological results, (10).

Data suggest that one third of pregnant breast cancer patient have Her-2 positive disease (11). However, one study has shown that application of trastuzumab during pregnancy increases the risk of oligohydramnios and anhydramnios and should not be recommended until postpartum (12). A recently published case report showed fetal growth retardation, oligohydramnios and right renal agenesis in a patient who became pregnant while receiving trastuzumab and pertuzumab for metastatic breast cancer, resulting in pregnancy termination (13).

Tamoxifen is a non-steroidal estrogen with both agonist and antagonist activity. The use of tamoxifen is not recommended during pregnancy, since tamoxifen and its metabolites interact with rapidly growing and developing embryonic or fetal tissues, resulting in a relatively high frequency of severe congenital anomalies such as ambiguous genitalia $(14,15)$.

Although chemotherapy is considered safe after the first trimester, only few studies have investigated the long-term effect of in utero exposure. Some chemotherapeutic agents are known to cross the placental barrier such as cisplatin (16), cyclophosphamide (17), doxorubicine (18) and methotrexate (19). Methotrexate has been associated with malformations of the central nervous system, skeletal, gastrointestinal, and cardiac malformations, and even fetal death (20).

In a review of 43 pregnant women given platinum-based chemotherapy, detectable cisplatin concentrations or platinum-DNA adducts were found in neonates who had been exposed to platinum derivatives during the third trimester (21). Recent studies have shown a relationship between platinum-based chemotherapy and fetuses small for gestational age (22). The long latent period of some cancers remains a problem for accurate risk identification.

\section{Fetal outcome}

There is no evidence that early termination of pregnancy improves prognosis. The decision to terminate pregnancy is, to a large extent, a personal choice of the woman or the couple, following extensive discussions with a multidisciplinary team (23).
Since pregnancy-associated breast cancer is a relatively rare disease, only few studies have investigated short and long-term effects of in utero fetal exposure to chemotherapy. An observational study which included 447 pregnant patients, 413 of whom had early breast cancer showed that even though infants exposed to chemotherapy in utero had a lower birthweight and more complications, these differences were not clinically significant and, since none of them was exposed to chemotherapy in the first trimester, were most likely related to premature delivery. A full-term delivery seems to be of outmost importance, since preterm birth was strongly associated to adverse events (24).

A recently published study on 81 pregnant patients being treated with anthracycline-based chemotherapy for breast cancer between 1992 and 2010 found no trend to indicate a higher rate of serious medical problems in the children of these patients, who were exposed to chemotherapy in utero, than that seen in the general population. Therefore it seems reasonable to conclude that treating breast cancer during the second and third trimesters with anthracycline-based chemotherapy does not jeopardize the outcome of the developing fetus $(25,26)$.

Lactation is contraindicated during chemotherapy, and if milk secretion is maintained throughout chemotherapy, breastfeeding can be allowed 3-4 weeks after the last administered dose of chemotherapy, since all chemotherapeutics have been detected in breast milk. Tissue fibrosis as a result of radiotherapy may inhibit lactation on the affected side in the future (27).

\section{Prognosis}

The prognosis of breast cancer in pregnant patients remains controversial. A recent retrospective study found no significant differences in overall survival, disease-free survival or distant recurrence rates between pregnant and non-pregnant breast cancer patients. Pregnancy associated status, a primary tumor larger than $5 \mathrm{~cm}$ and neoadjuvant chemotherapy as the primary treatment were significantly associated with an increased risk of local relapse. Interestingly, although pregnant patients have more locally advanced tumors, they did not have a higher rate of radical surgery than the control breast cancer group. Pregnancy associated status is a strong prognostic factor of 
local relapse in breast cancer, so authors recommend, when possible, radical surgery as the first treatment step $(28,29)$.

\section{Conclusion}

Considering the trend to postpone childbearing and the general increase in the incidence of breast cancer, the incidence of pregnancy-associated breast cancer is expected to increase. An individual multidisciplinary approach is needed for this difficult psychosocial and health problem. Treatment of pregnancy-associated breast cancer should follow the guidelines for non-pregnant patients as close as possible. Evidence suggest the safety of administration of certain chemotherapy after the first trimester of pregnancy. Radiotherapy, trastuzumab and antihormonal treatment are contraindicated during pregnancy. Pregnancy does not seem to worsen the prognosis of breast cancer patients. Most fetal complications are related to preterm delivery, which should therefore be avoided whenever is possible.

\section{REFERENCES}

1. Anderson JM. Mammary cancers and pregnancy. Br Med J. 1979;1:1124-7.

2. Wallack MK, Wolf JA Jr, Bedwinek J, Denes AE, Glasgow G, Kumar B, Meyer JS, Rigg LA, WilsonKrechel S. Gestational carcinoma of the female breast. Curr Probl Cancer. 1983;7:1.

3. Albreksten G, Heuch I, Kvale G. The short and long term effect of a pregnancy on breast cancer risk: a prospective study of 802,457 parous Norwegian women. Br J Cancer 1995;72:480-4.

4. Jernstrom H, Lerman C, Ghadirian P, Lynch HT, Weber B, Garber J, et al. Pregnancy and risk of early breast cancer in carriers of BRCA1 and BRCA2. Lancet 1999;354:1846-50.

5. Molckovsky A, Madarnas Y. Breast cancer in pregnancy: a literature review. Breast Cancer Res Treat. 2008, 108:333-8.

6. Theriault R, Hahn K. Management of breast cancer in pregnancy. Curr Oncol Rep. 2007;9:17-21.

7. Litton JK, Theriault RL, Gonzalez-Angulo AM. Breast cancer diagnosis during pregnancy. Womens Health (Lond Engl). 2009;5:243-249.

8. Basaran D, Turgal M, Beksac K, Ozyuncu O, Aran O, Beksacb MS. Pregnancy-Associated Breast Cancer: Clinicopathological Characteristics of 20 Cases with a Focus on Identifiable Causes of Diagnostic Delay. Breast Care (Basel). 2014;9(5):355-359.

9. Azim HA jr, Botteri E, Renne G et al. The biological features and prognosis of breast cancer diagnosed during pregnancy: a case-control study. Acta Oncol. 2012;51:653-61.

10. https://www.nccn.org/professionals/physician_gls/ pdf/breast.pdf

11. Loibl S. New Therapeutic Options for Breast Cancer during Pregnancy. Breast Care (Basel). 2008;3(3): 171-176.

12. Watson WJ. Herceptin (trastuzumab) therapy during pregnancy: association with reversible anhydramnios. Obstet Gynecol. 2005;105:642-3.

13. Yildirim N, Bahceci A. Use of pertuzumab and trastuzumab during pregnancy. Anticancer Drugs. 2018 Sep;29(8):810-813.

14. Tewari K, Bonebrake RG, AsratT, Shanberg AM. Ambiguous genitalia in infant exposed to tamoxifen in utero. Lancet 1997;350:183.

15. Braems G, Denys H, De Wever O, Cocquyt V, Van den Broecke R. Use of tamoxifen before and during pregnancy. Oncologist. 2011;16:1547-51.

16. Marnitz S, Köhler C, Oppelt P, Schmittel A, Favero G, Hasenbein K, Schneider A, Markman M: Cisplatin Application in Pregnancy: First in vivo Analysis of $7 \mathrm{~Pa}-$ tients. Oncology 2010;79:72-7.

17. D'Incalci M, Sessa C, Colombo N, de Palo G, Semprini AE, Pardi G. Transplacental passage of cyclophosphamide. Cancer Treat Rep. 1982;66:1681-2.

18. Karp GI, von Oeyen P, Valone F et al. Doxorubicin in pregnancy: possible transplacental passage.Cancer Treat Rep. 1983;67:773-7.

19. Al-Saleh E, Al-Harmi J, Al-Rashdan I, Al-Shammari M, Nandakumaran M. Maternal-fetal transport kinetics of methotrexate in perfused human placenta: in vitro study. J Matern Fetal Neonatal Med. 2007;20: 411-8.

20. Buhimschi CS, Weiner CP. Medications in pregnancy and lactation: Part 1. Teratology. Obstet Gynecol. 2009 Jan;113:166-88.

21. Mir O, Berveiller P, Ropert S, Goffinet F, Goldwasser F. Use of platinum derivatives during pregnancy. Cancer. 2008;113:3069-74.

22. de Haan J, Verheecke M, Van Calsteren K et al. Oncological management and obstetric and neonatal outcomes for women diagnosed with cancer during pregnancy: a 20-year international cohort study of 1170 patients. Lancet Oncol. 2018 Mar;19(3):337-346.

23. Royal College of Obstetricians and Gynaecologists. Pregnancy and Breast Cancer. Green-top Guideline No. 12. London: RCOG; 2004.

24. Loibl S, Han SN, von Minckwitz G et al. Treatment of breast cancer during pregnancy: an observational study. The Lancet. 2012;13,887-896.

25. Murthy RK, Theriault RL Barnett CM, Hodge S, Ramirez MM, Milbourne A, Rimes AS, Hortobagyi GN, Valero V, and Litton JK. Outcomes of children exposed in utero to chemotherapy for breast cancer. Breast Cancer Res. 2014;16:500. 
26. Shechter Maor G, Czuzoj-Shulman N, Spence AR, Abenhaim HA. Neonatal outcomes of pregnancy-associated breast cancer: Population-based study on 11 million births. Breast J. 2018; doi:12. 10.1111/tbj.13156.

27. Navrozoglou I, Vrekousis T, Kontostolis E, Dousias V, Zervoudis S, Stathopoulos EN, et al. Breast cancer during pregnancy: a mini-review. EurJ Surg Oncol. 2008;34:837-43.

28. Genin AS, De Rycke Y, Stevens D, Donnadieu A, Langer A, Rouzier R, Lerebours F. Association with pregnancy increases the risk of local recurrence but does not impact overall survival in breast cancer: A case-control study of 87 cases. Breast. 2016;30:222-7.
29. Rojas KE, Bilbro N, Manasseh DM, Borgen PI. A Review of Pregnancy-Associated Breast Cancer: Diagnosis, Local and Systemic Treatment, and Prognosis. J Womens Health (Larchmt). 2018 Nov 27. doi: 10.1089/ jwh.2018.7264.

Corresponding author: Lidija Beketić-Orešković, Department of Clinical Oncology, School of Medicine, University of Zagreb and Division of Radiotherapy and Medical Oncology, University Hospital for Tumors, Sestre milosrdnice University Hospital Center, Ilica 197, 10000 Zagreb,Croatia.e-mail: lidijabeketicoreskovic@gmail.com 